\title{
Targeted gene expression study of Salmonella enterica during biofilm formation on rocket leaves
}

\author{
Agapi I. Doulgeraki*, Maria Papaioannou, George-John E. Nychas \\ Department of Food Science and Human Nutrition, Laboratory of Microbiology and Biotechnology of Foods, Agricultural University of Athens (AUA), Iera \\ Odos 75, Athens, 11855, Greece
}

\section{A R T I C L E I N F O}

\section{Article history:}

Received 20 February 2015

Received in revised form

31 July 2015

Accepted 6 August 2015

Available online 8 August 2015

\section{Keywords}

Salmonella

Rocket

Biofilm formation

Gene expression

Stress response

\begin{abstract}
A B S T R A C T
In the present study, the ability of Salmonella Typhimurium to form biofilm community on rocket leaves and rocket extract at $10{ }^{\circ} \mathrm{C}$ and $20{ }^{\circ} \mathrm{C}$ was investigated. This goal was achieved with the study of expression of genes associated with biofilm formation and other functional roles. The obtained results showed that Salmonella growth was inhibited when cultured in rocket extract (liquid and solid state) and when grew directly to rocket leaves. The observed inhibition might be attributed to nutrient starvation to the specific growth media because of plant leaves's variability, cell physiology and antimicrobial compounds of rocket. In addition, gene expression study using Real-Time PCR showed that biofilm was formatted on solid media, while the entrance and adhesion of the microorganism within the plant held more strongly through the stomata of the plant leaves. Furthermore, genes associated with managing stress situations were overexpressed at $20^{\circ} \mathrm{C}$. From these results, it is indicated that further studies are needed to better determine the survival and/or growth of the pathogen as "real" biofilm cells on plants. In addition, the study on development and gene expression of biofilm cells is necessary in order to eliminate the specific pathogen and reduce the food-borne diseases it causes.
\end{abstract}

๑) 2015 Elsevier Ltd. All rights reserved.

\section{Introduction}

Vegetables are important components of a healthy and balanced diet, so high quantities are consumed worldwide every day. However, their consumption has been associated with foodborne illnesses. According to European Food Safety Authority (EFSA, 2013), highest priority levels worldwide were defined for leafy green vegetables, consumed as raw salad contaminated with pathogenic Escherichia coli, while Salmonella on/in leafy greens and tomatoes were also most highly graded. However, it was also reported that of in total 394 bacterial pathogen/FoNAO (food non-animal origin) associations indicated in the literature, 109 have been found with Salmonella spp., including multiple serovars (i.e. Agona, Durban, Enteritidis, Gustavia, Montevideo, Newport, Typhi, Typhimurium, Umbilo, and unspecified serovars). More specific, S. Typhimurium has been identified in association with honeydew, lettuce, basil, salad, vegetables, and salad vegetables (ECDC, 2008; Isara, Isah, Lofor, \& Ojide, 2010; Pui et al., 2011; Sagoo, Little, \& Mitchell,

\footnotetext{
* Corresponding author.

E-mail addresses: adoulgeraki@aua.gr (A.I. Doulgeraki), gjn@aua.gr (G.-J.E. Nychas).
}

2003a,b; Wetzel, Lee, Lee, \& Binkley, 2010). Berger et al. (2010) reported that numerous studies have investigated the potential sources of produce contamination in the supply chain both at the pre-harvest (in the field) and post-harvest stages.

During the pre-harvest phase, pathogen populations can establish themselves on growing crops. The risk can be amplified after harvest either by further direct contamination or by proliferation of existing pathogen populations during processing and post harvest handling procedures. It has been reported that, slicing, peeling or damage of plants releases nutrients and thus, facilitates growth of bacteria (Harris et al., 2003). These nutrients could also remain on industrial surfaces and affect bacterial survival, adhesion and biofilm formation, which further will be an important cross contamination source for leafy salads. Olaimat and Holley (2012) reviewed the studies related with the contamination sources and the pathogens survival or growth on fresh produce. The ability of the pathogens to form biofilm on the surface of leaves of different plants is also well reviewed. Although, several studies have been associated with this phenomenon, a few of them include in their study the microbial interactions with autochthonous biota which facilitate biofilm formation. To our knowledge-limited studies if any, have been conducted to investigate the virulence genes 
expression of pathogens during biofilm development on fresh produce. However, it needs to be consider that several factors have to be checked as infection requires the expression of genes not only coding virulence factors but also physiological processes such as stress response and adaptation. In this direction, the aim of this study was to monitor the differential gene expression of $S$. Typhimurium on rocket leaves in silico and in situ. In order to achieve this, the ability of this bacterium to develop a biofilm community cultivated as biofilm on rocket leaves or solid rocket extract versus planktonic mode were comparatively studied in the present work. Afterward, the expression of genes associated with biofilm formation, pathogenicity and other functional roles was examined.

\section{Materials and methods}

\subsection{Bacterial strain and preparation of inoculum}

In this experimental design, the strain Salmonella enterica subsp. enterica serovar Typhimurium CDC 6516-60 (ATCC 14028) was used. Cells from a $18 \mathrm{~h}$ culture $\left(37^{\circ} \mathrm{C}\right)$ were harvested by centrifugation $\left(5000 \times \mathrm{g}, 10 \mathrm{~min}\right.$, at $\left.4{ }^{\circ} \mathrm{C}\right)$, washed twice with $1 / 4$ quarter Ringer solution and finally resuspended in $1 / 4$ quarter Ringer solution, in order to be used as inoculum $\left(10-20 \mathrm{cfu} / \mathrm{mL}\right.$ or $\left.\mathrm{cm}^{2}\right)$.

\subsection{Rocket extract, leaves and gel cassette preparation}

Rocket leaves was purchased from a local supplier and transferred to the laboratory. After washing with running tap water, the leaves was dried, cut and mixed with equal volume of $\mathrm{dH}_{2} \mathrm{O}$. The mixture was left for $4 \mathrm{~h}$ under refrigerate temperature, while a pressure was applied every $30 \mathrm{~min}$ for better extraction of the rocket compounds. The rocket extract was obtained by filtration with whatman paper and sterilized $\left(121{ }^{\circ} \mathrm{C}\right.$ for $\left.15 \mathrm{~min}\right)$ before further use. In the case of solid medium, $15 \mathrm{~g} / \mathrm{L}$ agar was added before sterilization. Additionally, rocket leaves were transferred in squared petri dishes $(10 \times 10 \mathrm{~cm})$ in order to cover the whole surface. Samples prepared with leaves surface or stomata to contact the bottom of petri dish. Furthermore, gel cassette system $(10 \times 10 \mathrm{~cm})$ was prepared according to Brocklehurst, Mitchell, and Smith (1997) and autoclaved at $121^{\circ} \mathrm{C}$ for $15 \mathrm{~min}$. After sterilization, gel cassette system was filled with approximately $35 \mathrm{ml}$ sterile LB agar or rocket agar and let to solidify.

All samples were inoculated with 10-15 S. Typhimurium cells per $\mathrm{mL}$ (for broth media) or $\mathrm{cm}^{2}$ (for solid media) and incubated at 10 and $20^{\circ} \mathrm{C}$.

\subsection{Microbiological analysis}

All samples subjected to decimal serial dilutions in $1 / 4$ quarter Ringer solution for bacterial enumeration. For sampling of solid media (LB or rocket agar on gel cassette system and leaves), samples removed aseptically from gel cassette system or petri dish and placed in sterile stomacher bag along with $20 \mathrm{~mL} \frac{1}{1 / 4}$ quarter Ringer solution. For RNA collection, appropriate volume of different samples was centrifuged (5000 g, $10 \mathrm{~min}, 4{ }^{\circ} \mathrm{C}$ ) and washed pellet, resuspended in RNAlater solution and stored at $-80^{\circ} \mathrm{C}$ until further use. In parallel, the population was enumerated on LB agar after $18-24 \mathrm{~h}$ at $37^{\circ} \mathrm{C}$. In the case of leaves, XLD medium (incubation for $24 \mathrm{~h}$ at $37^{\circ} \mathrm{C}$ ) was used to differentiate Salmonella population from autochthonous biota, while LB agar enumerated after $24 \mathrm{~h}$ and $18-24 \mathrm{~h}$ at 30 and $37^{\circ} \mathrm{C}$, respectively.

\subsubsection{RNA isolation}

The manufacturer recommendations of The PureLink ${ }^{\circledR}$ RNA Kit (Ambion) were followed for total RNA extraction. The RNA extraction procedure was performed in duplicate, both for planktonic- and biofilm-derived samples. Each sample replicate was derived from independent bacterial cultures. RNA samples were stored at $-80^{\circ} \mathrm{C}$ until further use.

\subsubsection{Real-time RT-PCR}

The protocol described by the Primescript Reverse Transcriptase (Takara) was applied for cDNA synthesis. The cDNA was stored at $-20{ }^{\circ} \mathrm{C}$ until further use. Real-time PCR amplification was performed in 96-well plates in a StepOnePlus detection System (Applied Biosystems) using double-stranded DNA intercalating fluorescent agent SYBR green for product detection. Each well contained SYBR green Master Mix (Kapa Biosystems), 200 nM of each primer (Table 1 ) and $1 \mu \mathrm{L}$ template. PCR amplification was initiated at $95{ }^{\circ} \mathrm{C}$ for $3 \mathrm{~min}$, followed by 40 cycles at $95{ }^{\circ} \mathrm{C}$ for $20 \mathrm{~s}$ and $60{ }^{\circ} \mathrm{C}$ for $30 \mathrm{~s}$. Control PCRs were included to detect background contamination (no-template control). PCR specificity and product detection were checked post amplification by examining the dissociation curves of the PCR products. These melting curve profiles were generated by first heating the samples to $95^{\circ} \mathrm{C}$ and then cooling them to $60{ }^{\circ} \mathrm{C}$ and slowly heating them at $1.8{ }^{\circ} \mathrm{C} \mathrm{min}^{-1}-95{ }^{\circ} \mathrm{C}$ for detection of SYBR green fluorescence. Melting curve profiles were analyzed using StepOne software 2.1 (Applied Biosystems).

\section{Results and discussion}

The present study aimed to better understanding of biofilm formation of pathogenic bacteria like Salmonella on leafy salads. In order to better understand this phenomenon, the differential gene expression of this bacterium cultivated as biofilm on solid laboratory medium, solid plant extract and rocket leaves versus planktonic mode were comparatively studied in the present work. Initially, both type of cells (biofilm and planktonic cultures) were set up at 10 and $20^{\circ} \mathrm{C}$. In order to compare expression of different genes between biofilm and planktonic bacteria, the latter were also grown under exactly the same conditions, while total RNA was successfully isolates from both types of cells. In Fig. 1, Salmonella populations under such conditions are presented. From the obtained results, it seems that the growth of the microorganism was inhibited in rocket extract (liquid and solid state) and when grew directly to rocket leaves at both temperatures. Briefly, the final population of $S$. Typhimurium was affected from the rocket extract and rocket leaves as a difference of $1 \log \mathrm{cfu} / \mathrm{mL}$ and $4 \log \mathrm{cfu} / \mathrm{cm}^{2}$ was observed regarding the laboratory medium. This observed inhibition might be attributed to nutrient starvation to the specific growth media because of plant leaves's variability, cell physiology and antimicrobial compounds of rocket leaves. More accurately, early in Abdou, Abou-Zeid, El Sherbeeny, \& Abou-El-Gheat, 1972 reported the antimicrobial effect of rocket extract and seed oil on E. coli, S. typhi and Bacillus subtilis. Later, a similar effect of rocket seeds on E. coli was observed (Gulfraz et al., 2011). This antimicrobial effect has been attributed to high concentrations of glucosinolates (GSLs) (Adarsh, Geetanjali, Tarunpreet, \& Saroj, 2009; Tiendink et al., 1991).

Regarding the gene expression study of the present work was based on 7 different genes (Table 1), which were selected based on previous knowledge on their putative involvement in stress related mechanisms and colonization phenomena. Regarding these seven studied genes i.e. starvation, stress response, adaptation to nutrient deficiency, attachment, pathogenicity and quorum sensing, the differential expression was more associated with the planktonic and biofilm grown cells. In Figs. 2-8, the relative expression levels of these genes are presented. Additionally, it needs to be noted that the reference samples were planktonic cultures on LB broth at 10 
Table 1

Studied genes and primer synthesis.

\begin{tabular}{|c|c|c|c|c|}
\hline Gene & Function & Primer sequence $\mathrm{F}$ & Primer sequence $\mathrm{R}$ & Reference \\
\hline dps & $\begin{array}{l}\text { DNA starvation/stationary } \\
\text { phase protection protein } \\
\text { Dps }\end{array}$ & ATGCGCGGTGCTAACTTTAT & AAGTGATCCTGCACGTTATGG & In this study \\
\hline dppA & $\begin{array}{l}\text { Dipeptide transport system } \\
\text { substrate-binding protein }\end{array}$ & TTGACCGTCTGGTCTTCTCC & GACATCATCCAGCGGTTTTT & In this study \\
\hline $\mathrm{rpoH}$ & Starvation & CGTTAAAGTTGCAACCACGA & CCATCTCACGCACGTCTTTA & In this study \\
\hline sspH2 & Pathogenicity & GCACAACTGGCTGAAGATGA & CGTATTGCCCTTTTTCTGC & In this study \\
\hline sdiA & $\begin{array}{l}\text { Cell division control, } \\
\text { quorum sensing }\end{array}$ & ACGCGCAATGTTGTTACGC & ACCCACGCCGGAGGATAAGT & In this study \\
\hline $\operatorname{csgB}$ & Attachment & AGTGCCAGAGTACGCCAGGA & ACCGTAAGCGCTTTGCGATA & In this study \\
\hline osmY & Osmotic stress & GTCACCCTGAGCGGCTTTGT & CTTCACTGGTCGTGGCCGTA & In this study \\
\hline $16 s$ & & GATCATGGCTCAGATTGAACGCTGGCGG & CACCGCTACACCTGGAATTCTACCCCCCTC & $\begin{array}{l}\text { Eswarappa, Janice, } \\
\text { Balasundaram, } \\
\text { Dixit, \& Chakravortty, (2009) }\end{array}$ \\
\hline rpoD & & GTTGACCCGGGAAGGCGAAA & CAGAACCGACGTGAGTTGCG & Quiroz et al. (2011) \\
\hline rrsG & & GTTACCCGCAGAAGAAGCAC & CACATCCGACTTGACAGACC & Zheng et al. (2011) \\
\hline
\end{tabular}
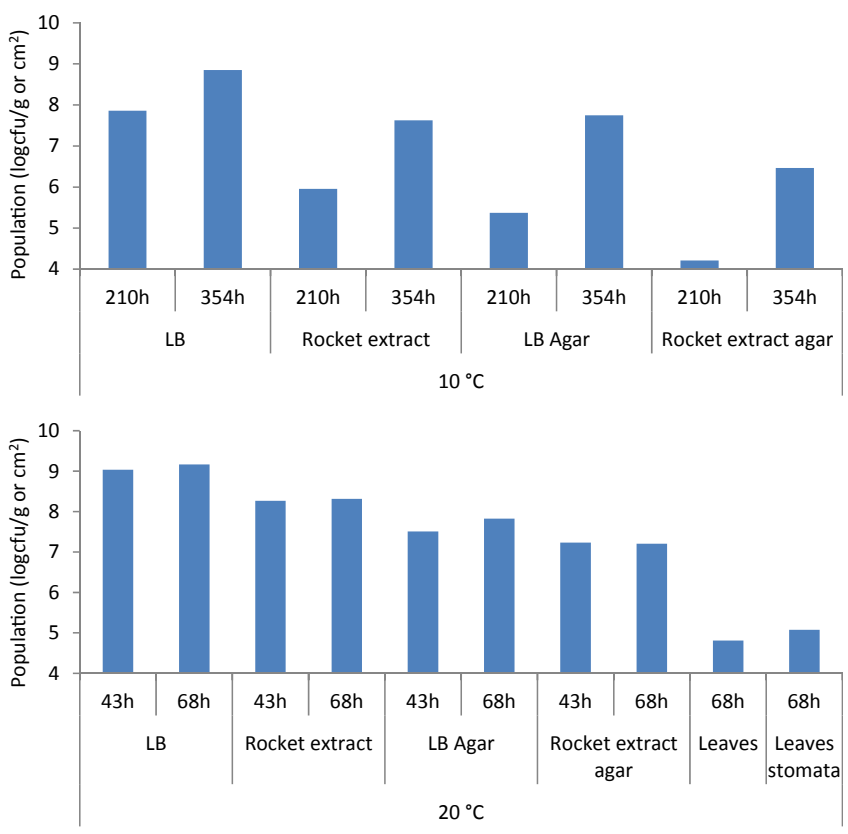

Fig. 1. Population of Salmonella Typhimurium cultured on different media at 10 and $20^{\circ} \mathrm{C}$. and $20^{\circ} \mathrm{C}$, while rrsG gene was chosen from the three tested (16S, rrsG and rpoD) as the reference housekeeping gene.

From these results, it was revealed that dps gene associated with DNA protection was up-regulated in all studied cases at $10^{\circ} \mathrm{C}$, but not at $20^{\circ} \mathrm{C}$. More specific, the expression of this gene was found to be affected from incubation temperature during growth on rocket extract, as up- and down-regulation was observed at 10 and $20^{\circ} \mathrm{C}$, respectively. On the other hand, up-regulation of dps gene was observed during growth on solid media (LB agar and rocket extract agar). The opposite results were observed during growth of the pathogen on rocket leaves, while dps gene expression was found to be also affected when the pathogen was inoculated on stomata. In Upregulation of dps gene was been reported previously for $S$. Enteritidis (Doulgeraki et al., (unpublished data); Giaouris, Samoilis, Chorianopoulos, Ercolini, \& Nychas, 2013) and for S. Typhimurium (Hamilton et al., 2009).

The periplasmic dipeptide-binding protein DppA was overexpressed in all cases but one. In the later case Salmonella was grown on rocket extract at $20^{\circ} \mathrm{C}$. The expression of this gene has been associated previously with biofilm growth of $S$. Enteritidis (Giaouris et al., 2013) and S. Typhimurium (Hamilton et al., 2009). It is worth noted that, in most of the cases a decreased expression level of this gene was accured during the incubation time, while the inoculation of the leaves from stomata side resulted in higher expression of dppA gene. Similar results were observed in the case

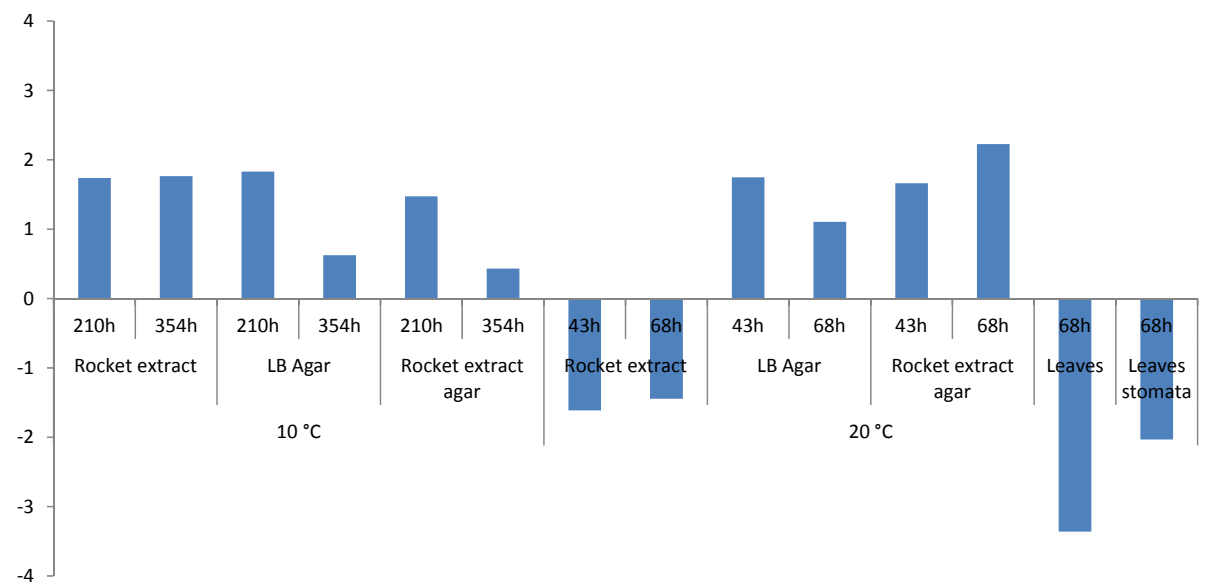

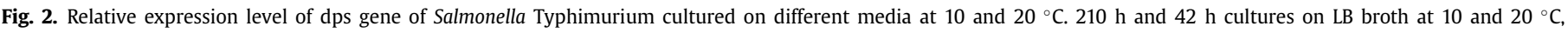
respectively, was used as reference, while $\operatorname{rrs}$ gene was used as housekeeping gene. 


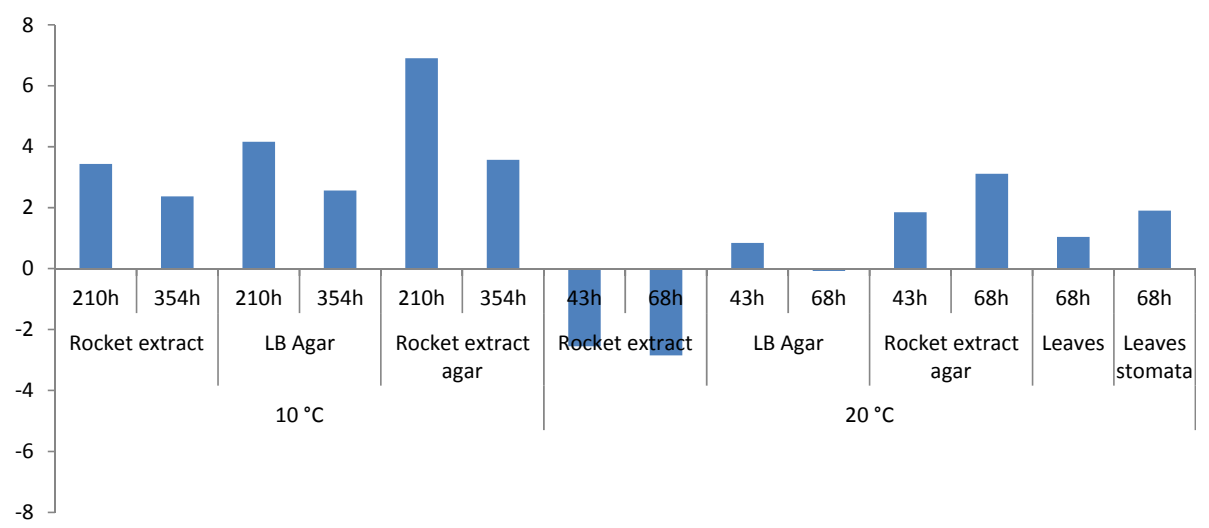

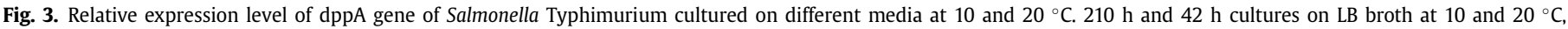
respectively, was used as reference, while rrsG gene was used as housekeeping gene.

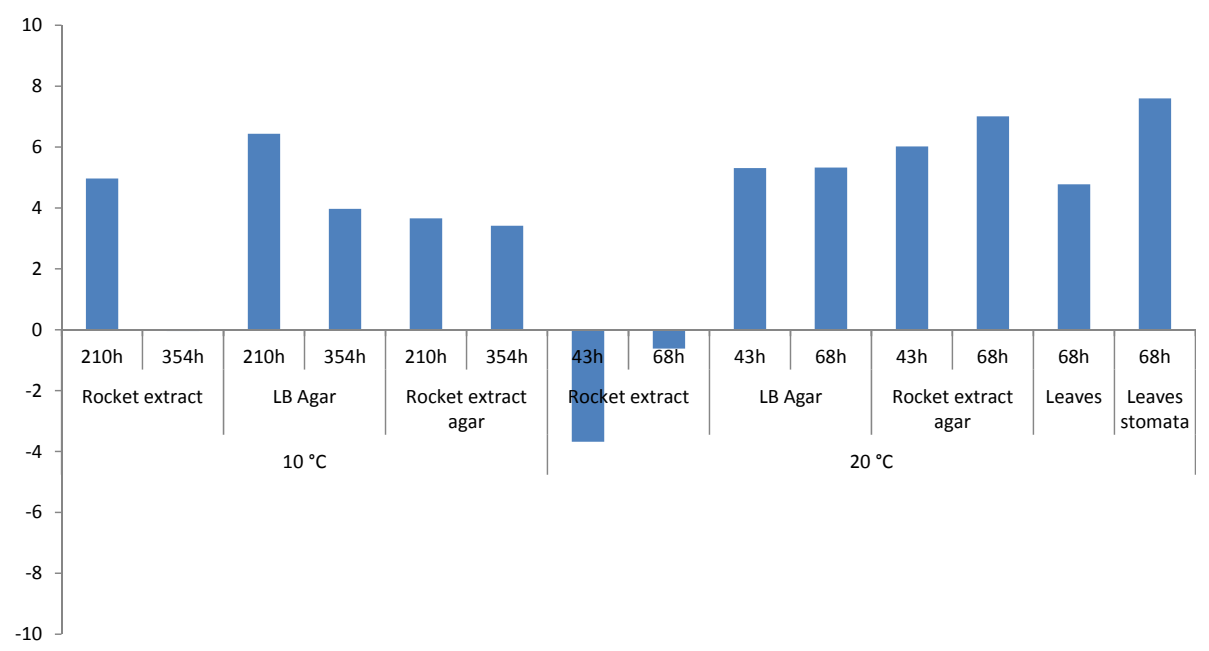

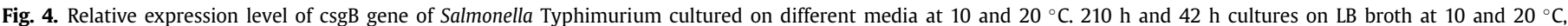
respectively, was used as reference, while $\operatorname{rrsG}$ gene was used as housekeeping gene.

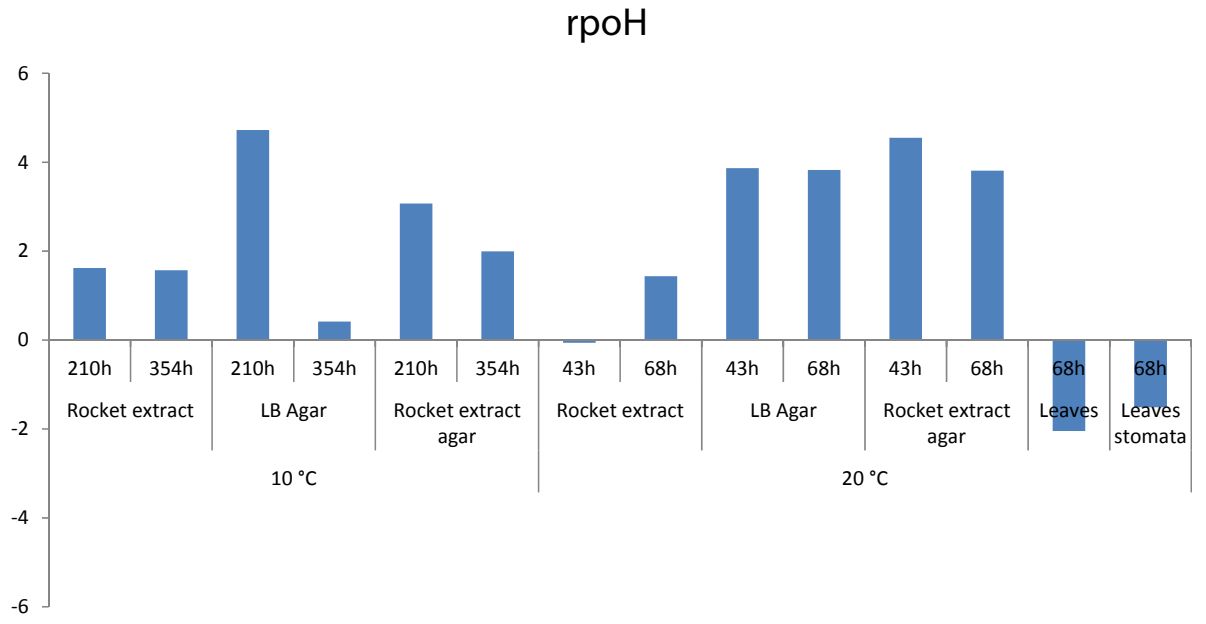

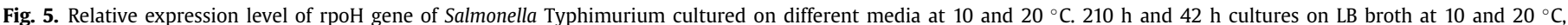
respectively, was used as reference, while rrsG gene was used as housekeeping gene.

of $\operatorname{csgB}$ gene, which is considered to be a regulator for BapA expression in Salmonella because a special binding motif, which is very similar to the CsgD-binding sequence in the adrA promoter, is present in the bapA promoter. Additionally, BapA was shown to be required for pellicle formation at the air-liquid interface and its expression was demonstrated to be coordinated with that of genes encoding curli and cellulose via CsgD (Latasa et al., 2005).

The rpoH gene which encodes the RNA polymerase sigma factor 


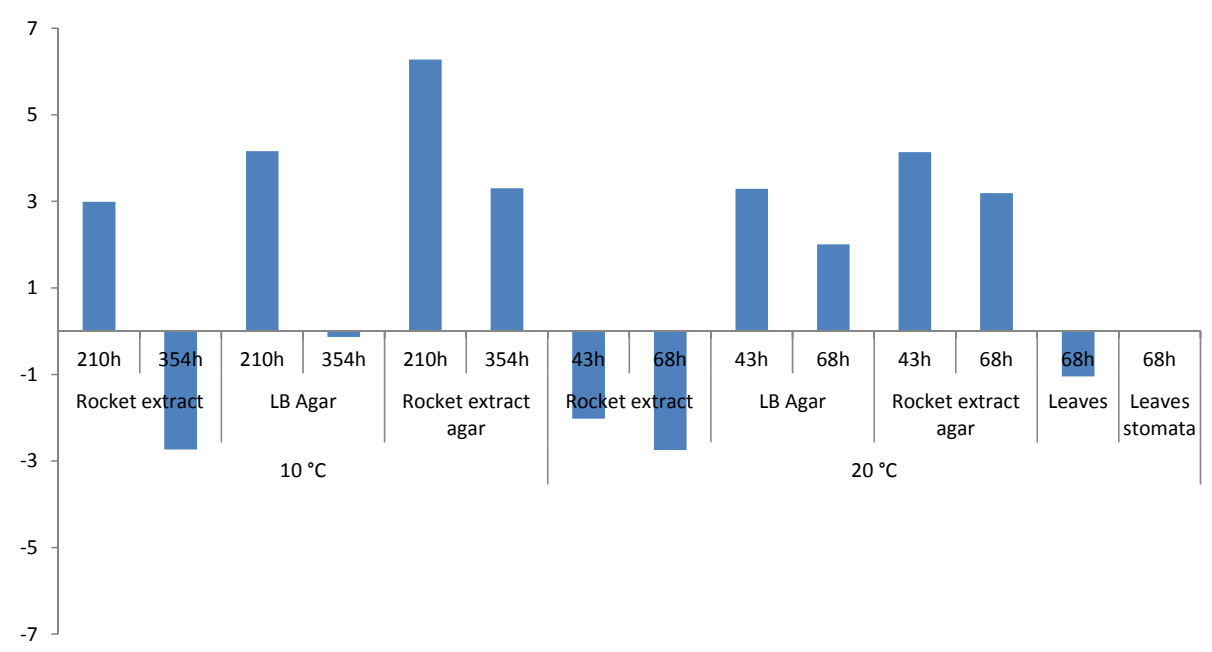

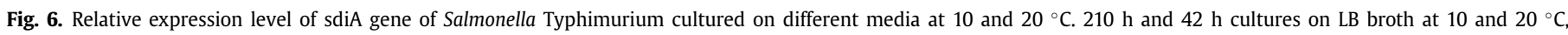
respectively, was used as reference, while rrsG gene was used as housekeeping gene.

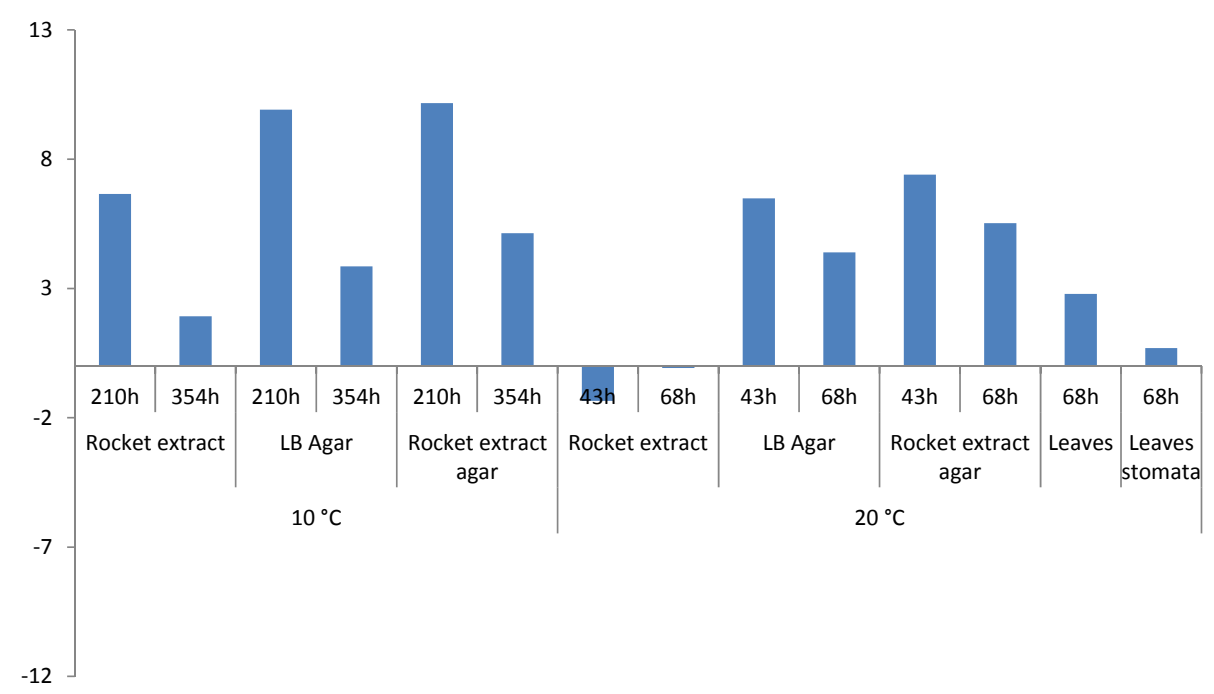

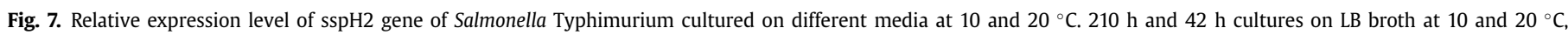
respectively, was used as reference, while rrsG gene was used as housekeeping gene.

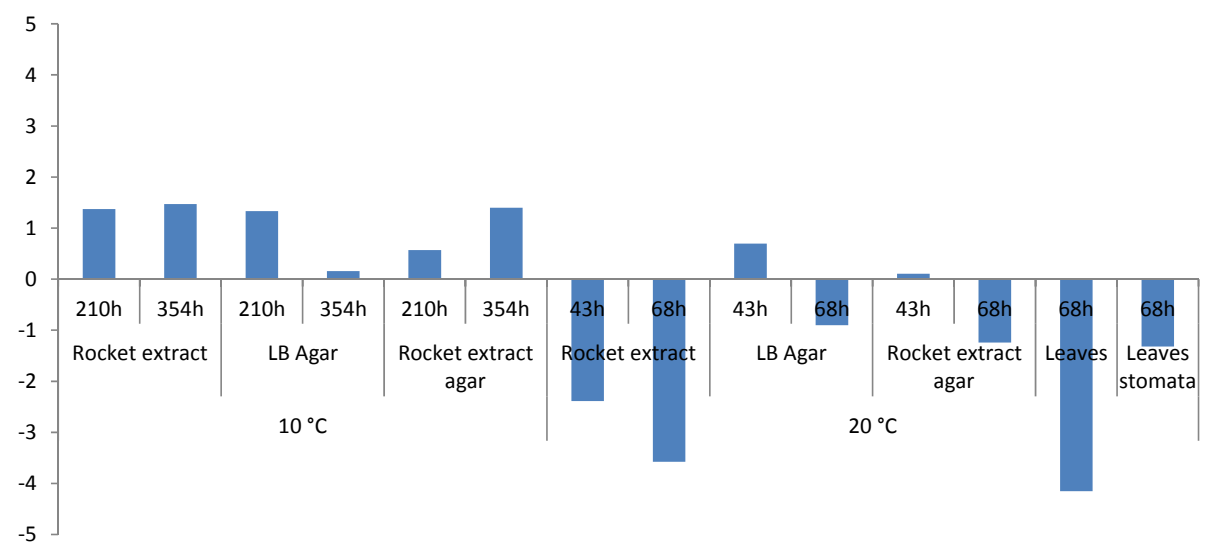

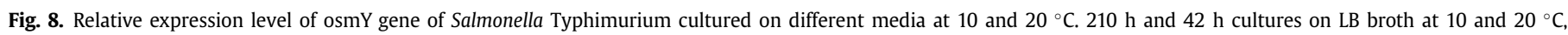
respectively, was used as reference, while $\operatorname{rrs}$ gene was used as housekeeping gene. 
$\mathrm{H}$ is known to play significant roles in stress responses. In a previous study, rpoH expression has been associated with biofilm growth (Hamilton et al., 2009). In the present study, this gene was down-regulated during growth of Salmonella on leaves, while a decreased expression related to the incubation time was observed in the case of solid media. However, a different trend was occurred in rocket extract broth, where expression of $\mathrm{rpoH}$ was increased during growth of Salmonella at $20^{\circ} \mathrm{C}$.

The expression of sdiA gene was also examined in this study (Fig. 6). This single analog protein, which is found in pathogenic bacteria of the intestine, is only known to activate genes that would help a single bacterium to adhere to host tissues, presumably because the presence of AHL-producing bacteria simply indicates that a particular host environment has been reached (Ahmer, 2004; Yao et al., 2006). In the present study, a decreased expression of sdiA gene related to the incubation time and higher temperature was observed in the case of solid media. Additionally, this gene was down-regulated in the case of rocket extract broth at $20{ }^{\circ} \mathrm{C}$ and $354 \mathrm{~h}$ at $10^{\circ} \mathrm{C}$. In the case of rocket leaves down-regulation of the gene or no expression of the gene has observed, suggesting that the expression of sdiA gene is more obvious in vitro. In a previous study, it was also reported that the SdiA system of Salmonella is most active in vitro during growth in motility agar at $37{ }^{\circ} \mathrm{C}$ (Ahmer, 2004). Additionally in accordance with this study, it was determined that $S$. Typhimurium does not respond well to AHLs in liquid LB medium but responds best in LB semisolid agar $(0.3,0.75$, or $1.5 \%$ agar) (Michael, Smith, Swift, Heffron, \& Ahmer, 2001). In the same work, they concluded that, in liquid cultures sdiA-dependent responses were 3- to 5-fold, while on semisolid agar the responses reached 14- to 17 -fold. It seems that temperature also affects the sdiA regulon, as it was also mentioned previously (Smith \& Ahmer, 2003).

It has been previously hypothesized that quorum sensing may be used by pathogenic species to prevent the expression of virulence factors until the population of bacteria has increased to a point at which victory is ensured (Michael et al., 2001). However, Ahmer (2004) reported that sdiA does not regulate either of the virulence-associated type III secretion systems of Salmonella. In this study, the pathogenicity was determined by focusing on the sspH2 effector protein, induced by SPI-2 (Fig. 7). Regarding the observed results similar trends were observed regarding the expression of sspH2 gene and sdiA gene in most of the cases, but leaves. In the later case, $\mathrm{sspH} 2$ was up-regulated while sdiA was down regulated.

Furthermore, the RpoS-regulated osmotically inducible gene, osmY, which has been found to be induced by both osmotic and growth phase signals (Yim \& Villarejo, 1992), found to be affected from the incubation temperature in the present work. Briefly, this gene was up-regulated and down-regulated at 10 and $20^{\circ} \mathrm{C}$. This gene was found previously to up-regulated during biofilm growth of S. enterica (Giaouris et al., 2013; Hamilton et al., 2009).

The findings of the present study could show that $S$. Typhimurium reacts as exposed to different types of stress when inoculated to a heat sterile plant extract at lower temperature. However further studies are needed to better determine the survival and/or growth of the pathogen as "real" biofilm cells on plant leaves. In addition, the study on development and gene expression of biofilm cells is necessary in order to eliminate the specific pathogen and reduce the food-borne diseases it causes.

\section{Acknowledgments}

This work was found by the action THALIS: "Biological Investigation Of the Forces that Influence the Life of pathogens having as Mission to Survive in various Lifestyles; BIOFILMS", falls under the Operational Programme (OP) "Education and Lifelong Learning
(EdLL)" and is co-financed by the European Social Fund (ESF) and National Resources.

\section{References}

Abdou, I. A., Abou-Zeid, A. A., El Sherbeeny, R. M., \& Abou-El-Gheat, H. Z. (1972). Antimicrobial activities of Allium sativum Allium cepa, Raphanus sativus, Capsicum frutescens, Eruca sativa and Allium kurrat on bacteria. Qualitas Plantarum et Materiae Vegetabiles, 1, 29-35.

Adarsh, P. V., Geetanjali, R., Tarunpreet, S. T. \& Saroj, A. (2009). Bio-protective effects of glucosinolates - a review. Food Science and Technology, 42, 1561-1572.

Ahmer, B. M. M. (2004). Cell-to-cell signalling in Escherichia coli and Salmonella enterica. Molecular Microbiology, 52, 933-945.

Berger, C. N., Sodha, V. S., Shaw, R. K., Griffin, P. M., Pink, D., Hand, P., et al. (2010). Fresh fruit and vegetables as vehicles for the transmission of human pathogens. Environmental Microbiology, 12, 2385-2397.

Brocklehurst, T. F., Mitchell, G. A., \& Smith, A. C. (1997). A model experimental gel surface for the growth of bacteria on foods. Food Microbiology, 14, 303-311.

Doulgeraki, A. I., Giaouris, E., \& Nychas, G.-J. E. (2015). Comparing the transcription patterns of selected genes of Salmonella enterica serovar Enteritidis PT4 between planktonic and biofilm cells on stainless steel surfaces under two temperature growth conditions, (unpublished data)

ECDC (European Center of Disease Control). (2008). Scientific report of EFSA: The community summary report on trends and sources of zoonoses, zoonotic agents and food-borne outbreaks in the European Union in 2008. online. Available from: http://www.efsa.europa.eu/en/efsajournal/pub/1496.htm.

EFSA. (2013). Food of plant origin: Production methods and microbiological hazards linked to food-borne disease. Reference: CFT/EFSA/BIOHAZ/2012/01 Lot 1 (Food of plant origin with high water content such as fruits, vegetables, juices and herbs). Supporting Publications 2013:EN-402.

Eswarappa, S. M., Janice, J., Balasundaram, S. V., Dixit, N. M., \& Chakravortty, D. (2009). Host-specificity of Salmonella enterica serovar gallinarum: insights from comparative genomics. Infection Geneticis and Evolution, 9, 468-473.

Giaouris, E., Samoilis, G., Chorianopoulos, N., Ercolini, D., \& Nychas, G. J. (2013). Differential protein expression patterns between planktonic and biofilm cells of Salmonella enterica serovar Enteritidis PT4 on stainless steel surface. International Journal of Food Microbiology, 162, 105-113.

Gulfraz, M., Sadiq, A., Tariq, A., Tariq, H., Imran, M., Qureshi, R., et al. (2011). Phytochemical analysis and antibacterial activity of Eruca sativa seed. Pakistan Journal of Botany, 43, 1351-1359.

Hamilton, S., Bongaerts, R. J., Mulholland, F., Cochrane, B., Porter, J., Lucchini, S., et al. (2009). The transcriptional programme of Salmonella enterica serovar typhimurium reveals a key role for tryptophan metabolism in biofilms. BMC Genomics, 10, 599.

Harris, L. J., Farber, J. N., Beuchat, L. R., Parish, M. E., Suslow, T. V., Garrett, E. H., et al. (2003). Outbreaks associated with fresh produce: incidence, growth and survival of pathogens in fresh and fresh-cut produce. Comprehensive Reviews in Food Science and Food Safety, 2, 78-141.

Isara, A. R., Isah, E. C., Lofor, P. V. O., \& Ojide, C. K. (2010). Food contamination in fast food restaurants in Benin City, Edo State, Nigeria: implications for food hygiene and safety. Public Health, 124, 467-471.

Latasa, C., Roux, A., Toledo-Arana, A., Ghigo, J.-M., Gamazo, C., Penadés, J. R., et al. (2005). BapA, a large secreted protein required for biofilm formation and host colonization of Salmonella enterica serovar Enteritidis. Molecular Microbiology, 58, 1322-1339.

Michael, B., Smith, J. N., Swift, S., Heffron, F., \& Ahmer, B. M. (2001). SdiA of Salmonella enterica is a LuxR homolog that detects mixed microbial communities. Journal of Bacteriology, 183, 5733-5742.

Olaimat, A., \& Holley, R. (2012). Factors influencing the microbial safety of fresh produce: a review. Food Microbiology, 32, 1-19.

Pui, C. F., Wong, W. C., Chai, L. C., Nillian, E., Ghazali, F. M., Cheah, Y. K., et al. (2011). Simultaneous detection of Salmonella spp, Salmonella typhi and Salmonella typhimurium in sliced fruits using multiplex PCR. Food Control, 22, 337-342.

Quiroz, T. S., Nieto, P. A., Tobar, H. E., Salazar-Echegarai, F. J., Lizana, R. J., Quezada, C. P., et al. (2011). Excision of an unstable pathogenicity island in Salmonella enterica serovar enteritidis is induced during infection of phagocytic cells. PLOS One, 10, e26031.

Sagoo, S. K., Little, C. L., \& Mitchell, R. T. (2003a). Microbiological quality of open ready-to-eat salad vegetables: effectiveness of food hygiene training of management. Journal of Food Protection, 66, 1581-1586.

Sagoo, S. K., Little, C. L., Ward, L., Gillespie, I. A., \& Mitchell, R. T. (2003b). Microbiological study of ready-to-eat salad vegetables from retail establishments uncovers a national outbreak of salmonellosis. Journal of Food Protection, 66, 403-409.

Smith, J. N., \& Ahmer, B. M. M. (2003). Detection of other microbial species by Salmonella: expression of the SdiA regulon. Journal of Bacteriology, 185, 1357-1366.

Tiedink, H. G. M., Malingre, C. E., van Broekhoven, L. W., Jongen, W. M., Lewis, J., \& Fenwick, G. R. (1991). Role of glucosinolates in the formation of N-nitroso compounds. Journal of Agricultural Food Chemistry, 39, 922-926.

Wetzel, K., Lee, J., Lee, C. S., \& Binkley, M. (2010). Comparison of microbial diversity of edible flowers and basil grown with organic versus conventional methods. Canadian Journal of Microbiolology, 56, 943-951. 
Yao, Y., Martinez-Yamout, M. A., Dickerson, T. J., Brogan, A. P., Wright, P. E., \& Dyson, H. J. (2006). Structure of the Escherichia coli quorum sensing protein SdiA: activation of the folding switch by acyl homoserine lactones. Journal of Molecular Biology, 355, 262-273.

Yim, H. H., \& Villarejo, M. (1992). osmY, a new hyperosmotically inducible gene, encodes a periplasmic protein in Escherichia coli. Journal of Bacteriology, 174 3637-3644.

Zheng, J., Tian, F., Cui, S., Song, J., Zhao, S., Brown, E. W., et al. (2011). Differentia gene expression by RamA in ciprofloxacin-resistant Salmonella Typhimurium. PLOS One, 7, e22161. 